\title{
Implementation of digital performance assessment to measure pharmacy physics laboratory skills
}

\author{
Meiry Akmara Dhina 1, a *, Ginayanti Hadisoebroto 1, b, Sugeng Rifqi Mubaroq 2, c, Iyan Gustiana 3, d \\ ${ }^{1}$ Universitas Al-Ghifari, Jl. Cisaranten Kulon No. 140, Kota Bandung, Jawa Barat, 40293, Indonesia. \\ ${ }^{2}$ Universitas Pendidikan Indonesia. Jl. Dr. Setiabudhi No. 229 Bandung Jawa Barat, 40154, Indonesia \\ ${ }^{3}$ Universiti Malaysia Terengganu. Kuala Terengganu, Terengganu 21300, Malaysia \\ a meiryakmaradhina@gmail.com, ${ }^{b}$ gina.hs11@gmail.com, c mubaroq@upi.edu, dP4258@pps.umt.edu.my \\ * Corresponding Author.
}

Received: 10 November 2020; Revised: 11 January 2021; Accepted: 27 January 2021

\begin{abstract}
This study was motivated by the fact that laboratory skills assessment did not have a specific standard for each assessment. Student performance and skills in doing practicum are not well observed and measured. Meanwhile, the assessment of skills in pharmaceutical physics laboratory learning is considered important. An alternative assessment that can measure pharmaceutical physics laboratory skills is to use performance assessment. This research has integrated the work assessment in digital form with the existing web-based electronic module (e-mulsi). Application testing needs to be done to determine the digital performance assessment's effectiveness in assessing the pharmacy physics laboratory's skills. A system test and user test do this. System testing is done by white box testing. Meanwhile, user testing is carried out with an instrument in the form of a questionnaire to laboratory assistants and lecturers as users of the application's performance assessment application. The digital performance assessment system's performance test results using GTMetrix ranged from $85 \%$ - 62\%. This performance assessment application greatly helped the results of the questionnaire for laboratory assistants and lecturers. It greatly facilitated the archiving of each students process in the form of an information technology data base. Lecturers also find it very helpful because the value processing process is easier for applications to do, reducing data processing errors.

Keywords: digital performance assessment; laboratory skills; pharmacy physics
\end{abstract}

How to Cite: Dhina, M. A., Hadisoebroto, G., Mubaroq, S. R., \& Gustiana, I. (2021). Implementation of digital performance assessment to measure pharmacy physics laboratory skills. Momentum: $\quad$ Physics Education Journal, 5(1), 65-72. https://doi.org/10.21067/mpej.v5i1.5146

\section{Introduction}

Laboratory skills are the ability of students to prepare and design and arrange equipment and materials for experiments to be carried out in the laboratory during practice. Laboratory practices may help students learn and have scientific abilities because students are familiar with the preparation of instruments, the management of resources, the identification of problems, the understanding of phenomena, the analysis of data, the determination of provisional estimates and the results obtained by discovering new things from previously acquired concepts (Chu \& Leighton, 2019; Dhina, Hadisoebroto, \& Mubaroq, 2019; Hofstein \& Lunetta, 2004). Practicum is an integral component of the pharmacy physics learning process. Laboratory practice is used for a more in-depth method of learning theory and improving laboratory skills for students (Darmaji et al., 2019; Huda et al., 2020; Malik et al., 2018).

A laboratory is an important place where new knowledge is generated and validated in scientific experiments (Aji et al., 2019). A laboratory is also a place for students to obtain the opportunity 
to have direct experience in solving problems that are raised from the observed phenomena or the theories they are learning. Laboratory-based learning, combined with guided practice in the laboratory, is learning science concepts to enable students to have direct experience solving problems from the phenomena and hypotheses being studied. The content to be learned in the laboratory must be examined by lecturers since more complex learning content is carried out in the laboratory while simplified learning content is carried out concurrently with the learning process (Chu \& Leighton, 2019; Huda et al., 2020; Malik et al., 2018).

Laboratory experiments engage students in the exploration and instruction of first-hand knowledge. This form of practice is an important part of successful science teaching. Laboratory experiments involve students in scientific inquiry, which brings them in a position to ask questions, pose solutions, make predictions, observe, organize data, explain patterns (Hofstein, 2017; Lederman et al., 2019; Topalsan, 2020). These laboratory experiments allow students to plan and participate in investigations or participate in activities that improve their technical laboratory skills. These technical skills are observation skills, hypothesis skills, and communication skills (Hofstein, 2017; Molvinger et al., 2020; Rodriguez \& Towns, 2018).

Observational abilities involve tasks requiring the use of the five senses through vision, hearing, smell, taste and touch (Dewanti, 2019; Siswanto et al., 2018). Interpretation skills include interpreting the results of observations by recording the results of observations separately between main and side results, connecting observations, finding patterns and regularities from observation, and concluding (Franco, 2016; Ohn \& Ohn, 2020). Hypothetical skills enable student to stating between two variables or proposing an approximate answer to an event (Mutlu \& Şeşen, 2016). Experiment planning skills constitutes a series of activities planning activities, including determining experimental variables, determining activity objects, and work steps. Further, experimental planning skills also involve the skills to utilize tools and materials related to experiment.

Experimental skills include the skills to carry out experimental steps to data processing (Mutlu \& Şeşen, 2016; Oktiawan et al., 2019). Communicating skills are those skills that are both verbal and written in order to convey knowledge accurately and precisely. Communication skills consist of systematically and clearly presenting experimental findings in charts, graphs, diagrams, describing experimental effects, preparing and producing reports (Istiantara et al., 2019).

The issue that has arisen thus far is that students could still not independently practice and do not comprehend content from the practimc. One of the reasons of this issue is that during the practicum of pharmacy physics, students have not mastered performance abilities.nt The lecturers prefer to determine the final outcome only, or cognitive achievement only. To objectively and creatively promote self-confidence in studying pharmacy physics, performance skills are important in pharmacy physics practicum activities. The performance of laboratory skills depends on the consistency of and evaluation of the training program. To solve this problem, performance assessment is critical (Dhina, Hadisoebroto, \& Mubaroq, 2019).

It can be assumed that performance assessment is a test of practice. Students are expected to practice and conduct multiple tasks in this test and then carry out an assessment of students based on the evaluation criteria. Pharmacy physics practice performance assessment is an examination that requires students to perform several performances in the practicum of pharmacy physics. It is important to see process aspects, outcomes and experimental work through a performance evaluation. Professional lecturers, both in terms of experience, attitudes, and skills, will record overall student development. Good learning will not succeed without good assessment. The assessment commonly used to measure student skills is performance assessment (Susilaningsih et al., 2018).

Performance assessment provides positive benefits for an objective, measurable, and comprehensive assessment process for the final ability of student learning outcomes (Ghofur et al., 2020; Mubarok et al., 2018). Performance assessment can be used to assess laboratory skills. The performance assessment application concluded that the development of performance assessment tools increased student interest in practicum activities, motivated students in learning, and effectively helped lecturers measure student skills and attitudes. Practicum equipped with a performance assessment rubric can achieve learning completeness. Student character can be built during 
practicum activities, including discipline, honesty, independence, curiosity, responsibility, and collaboration (Ghofur et al., 2020; Masrukan \& Elmagustilla, 2020; Mubarok et al., 2018).

This research aims at continuing previous research on digitizing practicum modules (e-mulsi) (Dhina, Hadisoebroto, \& Mubaroq, 2019; Dhina, Hadisoebroto, Mubaroq, et al., 2019). A digital platform has been made to make it easier for students to do a practicum in the laboratory by utilizing digital modules. Performance assessment is integrated into the digital platform so that lecturers can assess student practicum in a more comprehensive and real-time manner. However, in this case, we want to do a test to find out how effective this digital performance assessment is in assessing the pharmacy physics laboratory's skills.

\section{Method}

This study aims at determining the digital performance assessment's effectiveness in assessing a pharmacy physics laboratory skill. This research tried to examine system test and user test. White box testing for system testing (Syaikhuddin et al., 2018). The researchers obtained the test case results with this test method by looking at the procedural design control structure. This method was based on attentive observation of an application's procedural details regardless of the codes used to design the software. The first step was testing the user interface (UI), which aims at determining the interface elements' functionality in each digital performance assessment page (Csontos \& Heckl, 2020; Ramakrishnan \& Kaur, 2020). Functional testing was carried out to test the system when it is run online. Functional testing was carried out under ISO 9126 (Wang et al., 2019). While Performance testing was carried out on the aspects of reliability and efficiency using the GTMetrix application (GTmetrix/Website Speed and Performance Optimization, n.d.). Several factors that should be considered in testing reliability and efficiency were bandwidth and web hosting capacity. Both of them could affect the speed and performance of web-based applications. Meanwhile, user testing was carried out with an instrument in the form of a questionnaire to laboratory assistants and lecturers as users of the digital performance assessment.

\section{Results and Discussion}

The system was developed by adding a performance assessment to the application by managing the practicum performance checklist. The laboratory assistant added assessment points with a checklist form as presented in Figure 1. This digital performance assessment element has several important functions as follows: New Element button to add checklist items; Edit Button To edit a checklist item; and red button to delete checklist items. Before the system deletes data, it issues a warning message to avoid human error. After the checklist form was built into the digital performance assessment, the researchers carried out a system integration in the practicum module and practicum reports, which provided output in the students' final practicum scores.

The input stage of practicum performance data was carried out as presented in Figure 2. This was done by selecting students to be assessed, then clicking the Present Value button. Then, the lecturer checked or selected the checklist table according to the student performance results, then clicked the Submit button to save to the database, and the lecturer could see the results in the field of study. After the laboratory assistant evaluated the practicum's performance, the lecturer would see the practicum score's recapitulation, which calculates practicum performance assessments and student report assessments as shown in Figure 3.

Numerous improvements have been made to the implementation of the application. In other words, an additional process has been carried out to validate the accounts registered as students. This was done because there were a lot of duplicate accounts due to students registering twice because they forgot their passwords. The export data table button was indeed added as a whole. These were done because the lecturer needs the total value of the data. Performed performance assessment control can be carried out when the students are doing the practicum properly, setting the practicum time, and the laboratory assistant time for performance assessment must be the same (Samuelson et al., 2017; Sompuram et al., 2018). 
Momentum: Physics Education Journal, 5 (1), 2021, 68

Meiry Akmara Dhina et al
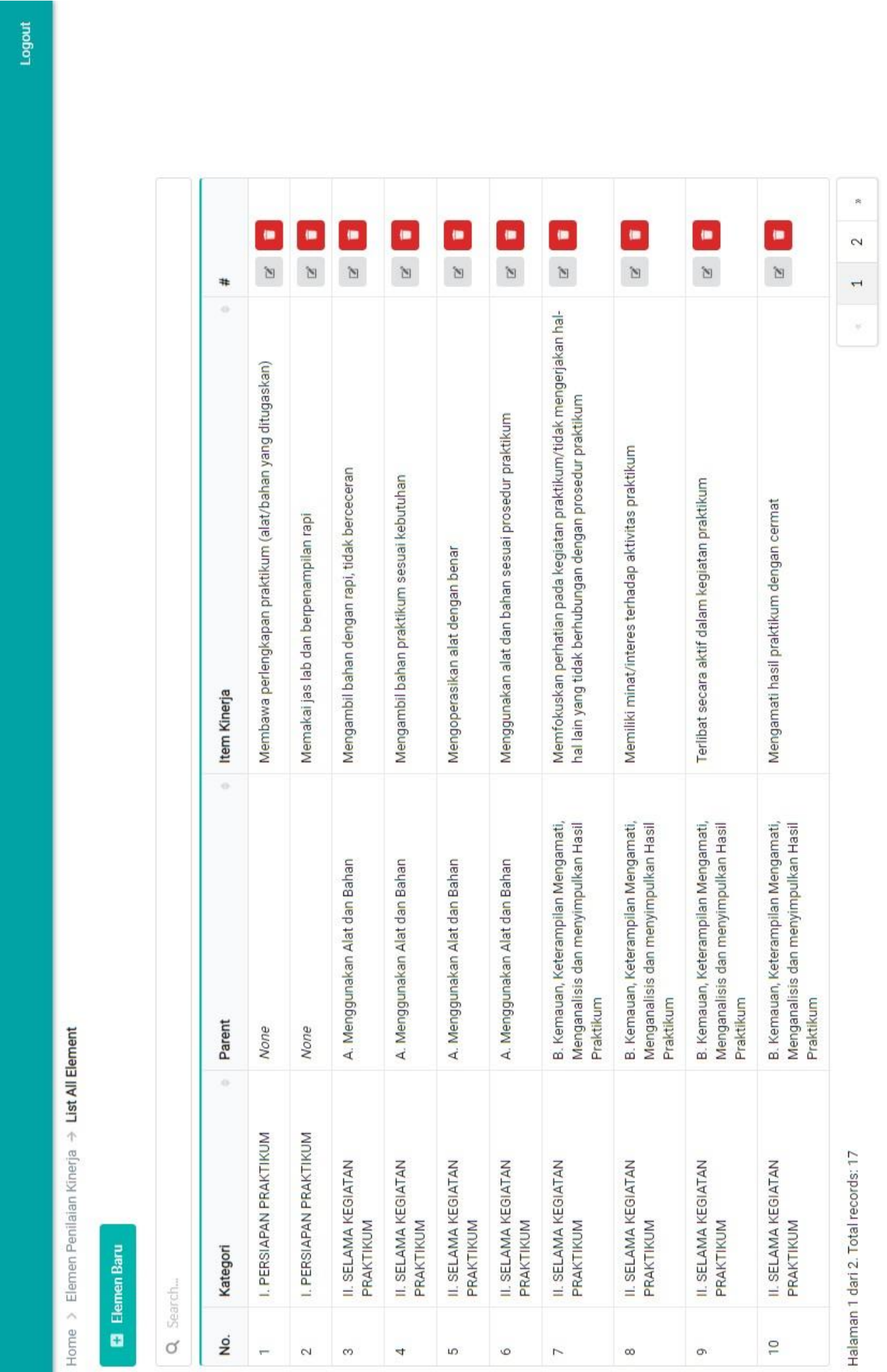

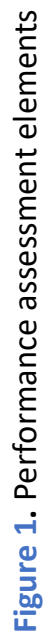


Momentum: Physics Education Journal, 5 (1), 2021, 69

Meiry Akmara Dhina et al

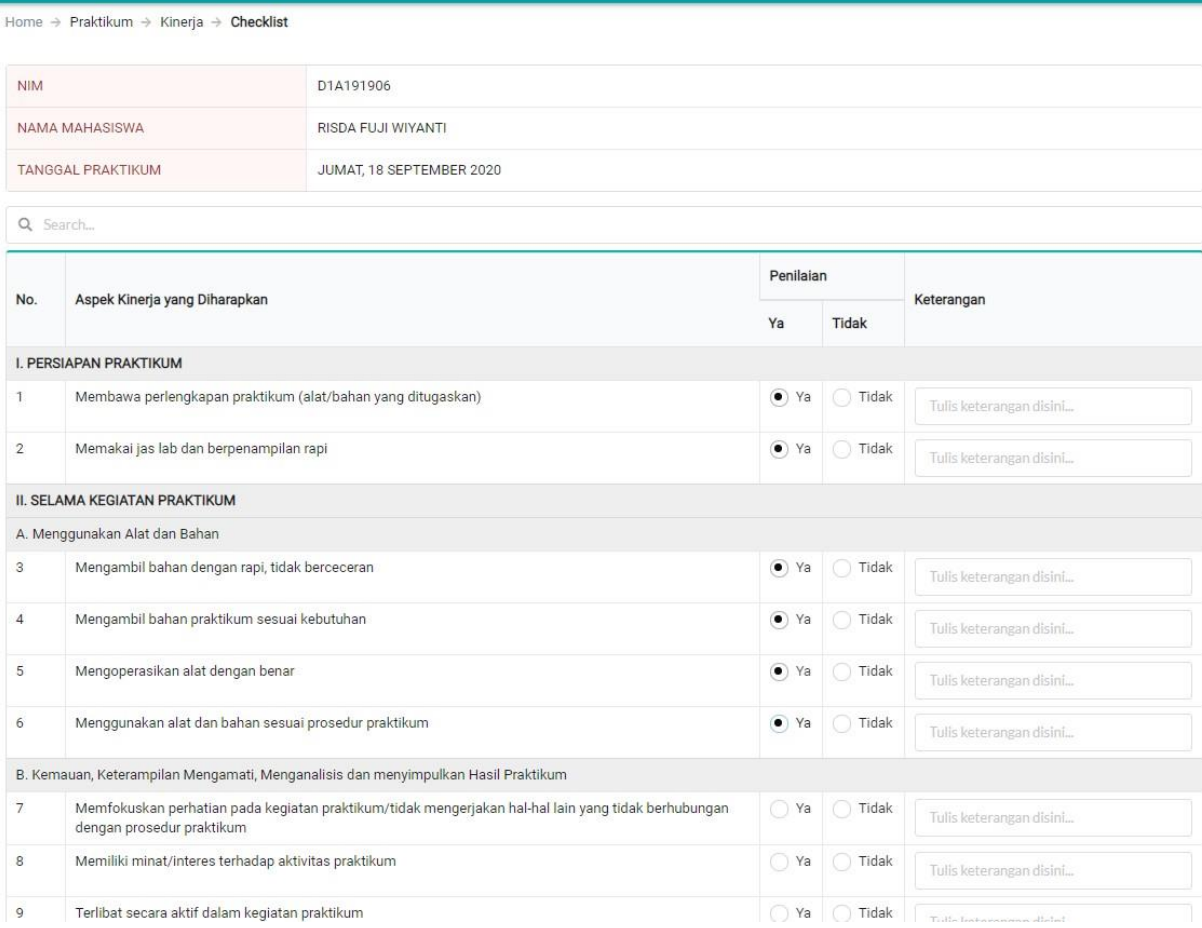

Figure 2. Practicum performance assessment form

\begin{tabular}{|c|c|c|c|c|}
\hline \multicolumn{5}{|c|}{$\begin{array}{l}\text { Rekapitulasi Nela Prakitivum } \\
\text { Modul Praktikum } \\
\text { Farmasi Fisika } 1\end{array}$} \\
\hline \multicolumn{5}{|c|}{ Excef PDF } \\
\hline \multirow{2}{*}{ No. } & \multirow{2}{*}{ Mahasiswa } & \multicolumn{2}{|c|}{ Elemen Nitai } & \multirow{2}{*}{ Nilat } \\
\hline & & Laporan & Checklist & \\
\hline 1 & - Syifa Nurul Aulia & 57 & 19 & 38 \\
\hline 2 & Itham Fajar budilaksana & 40 & 70 & s5 \\
\hline 3 & MINA LENI REBA & 18 & 67 & 42.5 \\
\hline 4 & . Cintarsish & 55 & 61 & 58 \\
\hline 5 & Fitri Herswati & 10 & 52 & 31 \\
\hline 6 & - Naril ffriani & 54 & 52 & 53 \\
\hline 7 & Rohandi & 89 & 49 & 69 \\
\hline 8 & Ekra Yuniza & 35 & 46 & 40.5 \\
\hline 9 & . Dior Andita & 9 & 28 & 59.5 \\
\hline 10 & Dest Aspiras i Hia & 91 & 57 & 74 \\
\hline Halamar & 1 dari 16. Total records: 160 & 1 & 4 & - \\
\hline
\end{tabular}

Figure 3. Recapitulation of practicum assessment

System tests on the application of the digital performance assessment have been carried out. Functional testing aimed at testing the functionality of the system when it is running online. Performance testing using GTMetrix is shown in Figure 4. The output of the digital performance assessment application ranges from 85 per cent to 62 percent.

Performance Scores

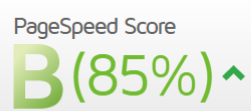

YSlow Score

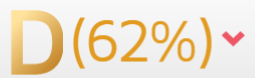

Page Details

\begin{tabular}{|l|l|l}
\hline Fully Loaded Time & Total Page Size & Requests \\
\hline $10.1 S^{`}$ & $648 \mathrm{~KB} \wedge$ & $41 \wedge$
\end{tabular}

Figure 4. The results of testing the digital performance assessment using Gtmatrix 
Application testing shall be carried out by collecting data in questionnaires to laboratory assistants and lecturers as users of application-related performance assessment applications. The results of the questionnaire for laboratory assistants and lecturers are shown in Figure 5. Laboratory assistants and lecturers find this application of performance assessment very worthwhile because it greatly facilitates the archiving of each student's process in an information technology database. It is also very helpful to readers, as the process of value processing is easier for applications to do, reducing data processing errors.

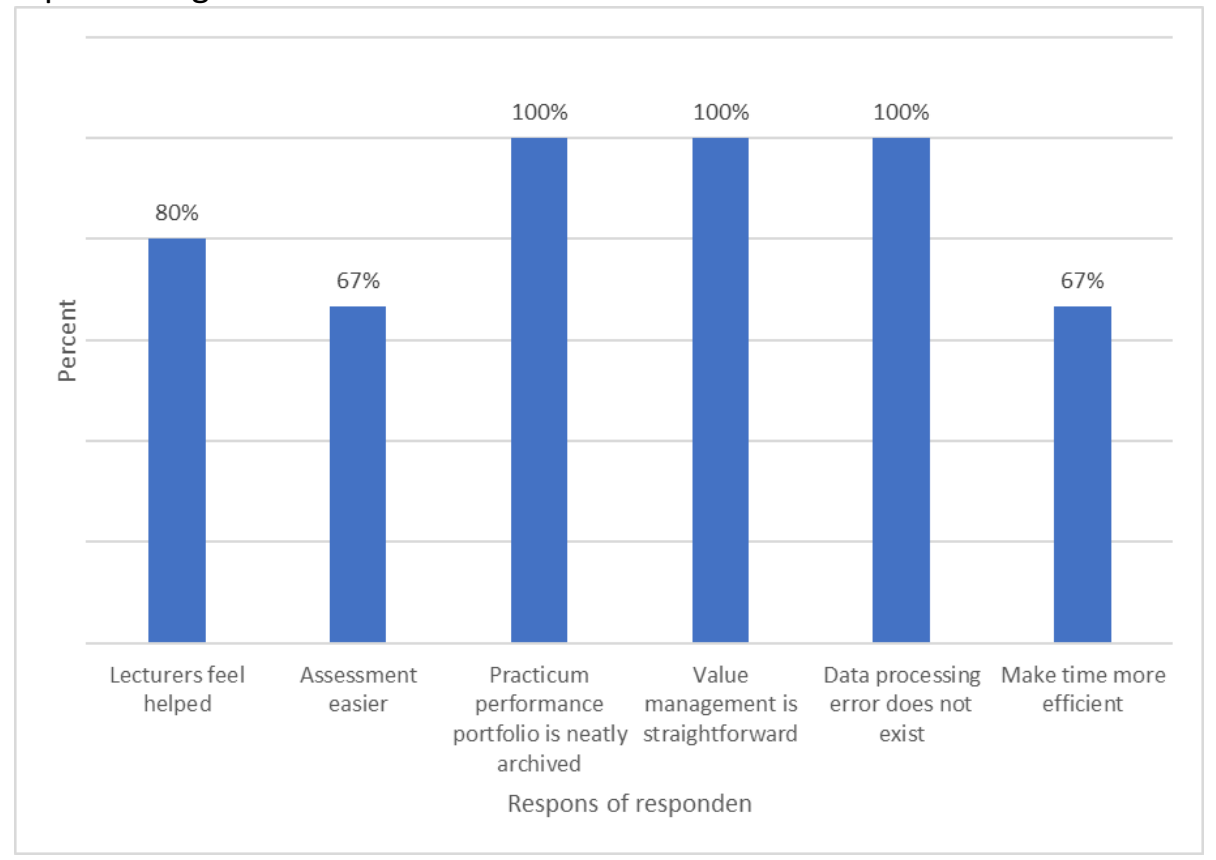

Figure 5. Graph of user experience

\section{Conclusion}

The implementation of the digital performance assessment is integrated with the existing webbased electronic module (e-mulsi) designed as a learning assessment tool in the Physical Pharmacy Laboratory. Digital assessments provide a variety of facilities for lecturers and laboratory assistants to assess student performance skills during practical work in a more comprehensive laboratory. Lecturers can evaluate the entire laboratory learning process, not only the final result, but also the cognitive value. It has the advantage of facilitating the process of archiving for each student in the form of an information technology database. It is also very helpful to readers, as the process of value processing is easier for applications to do, reducing data processing errors.

\section{Acknowledgment}

This research was funded by Deputy for Strengthening Research and Development, Ministry of Research and Technology / National Research and Innovation Agency, Republic of Indonesia.

\section{References}

Aji, S. D., Aprianto, R. D., Abdullah, A. G., \& Hudha, M. N. (2019). Physics Education (PhyEdu): Mechanical wave media for physics learning. Journal of Physics: Conference Series, 1402(6), 066068. https://doi.org/10.1088/1742-6596/1402/6/066068

Chu, M.-W., \& Leighton, J. P. (2019). Enhancing digital simulated laboratory assessments: A test of pre-laboratory activities with the learning error and formative feedback model. Journal of Science Education and Technology, 28(3), 251-264. https://doi.org/10.1007/s10956-018-9763-z

Csontos, B., \& Heckl, I. (2020). Accessibility, usability, and security evaluation of Hungarian government websites. Universal Access in the Information Society, 1-18. 
https://doi.org/10.1007/s10209-020-00716-9

Darmaji, D., Astalini, A., Kurniawan, D. A., Parasdila, H., Irdianti, I., Susbiyanto, S., Kuswanto, K., \& Ikhlas, M. (2019). E-module based problem solving in basic physics practicum for science process skills. International Journal of Online and Biomedical Engineering (IJOE), 15(15), 4. https://doi.org/10.3991/ijoe.v15i15.10942

Dewanti, B. A. (2019). Activities assessment as a tool to measure students' observation skills in science learning. Science Education and Application Journal, 1(1), 17. https://doi.org/10.30736/seaj.v1i1.94

Dhina, M. A., Hadisoebroto, G., \& Mubaroq, S. R. (2019). Development of e-practicum module for pharmacy physics learning. Momentum: Physics Education Journal, 3(2), 95-102. https://doi.org/10.21067/mpej.v3i2.3763

Dhina, M. A., Hadisoebroto, G., Mubaroq, S. R., Puspa, R. V. M., \& Deswati, D. A. (2019). E-mulsi: The digital module for pharmacy physics lab work. Journal of Physics: Conference Series, 1402(4), 044076. https://doi.org/10.1088/1742-6596/1402/4/044076

Franco, A. (2016). What do Ode to Joy, the Nobel Peace Prize, Umbrellas and Cartoons Have in Common? Why critical thinking matters and how higher education moulds. Higher Education for the Future, 3(1), 108-124. https://doi.org/10.1177/2347631115610231

Ghofur, A., Masrukan, M., \& Rochmad, R. (2020). Mathematical literacy ability in experiential learning with performance assessment based on self-efficacy. Unnes Journal of Mathematics Education Research, 10(A). https://journal.unnes.ac.id/sju/index.php/ujmer/article/view/39414

GTmetrix/Website Speed and Performance Optimization. (n.d.).

Hofstein, A. (2017). The role of laboratory in science teaching and learning. In Science education (pp. 355-368). Brill Sense. https://brill.com/view/book/edcoll/9789463007498/BP000027.xml

Hofstein, A., \& Lunetta, V. N. (2004). The laboratory in science education: Foundations for the twenty-first century. Sci Ed, 88(1), 28-54. https://doi.org/10.1002/sce.10106

Huda, S., Hartono, H., \& Masturi, M. (2020). The development of authentic scientific inquiry assessment to measure the laboratory skills. Journal of Physics: Conference Series, 1567(2), 022071. https://doi.org/10.1088/1742-6596/1567/2/022071

Istiantara, D. T., Mafudi, I., Handhika, J., Huriawati, F., Astutik, S. W., \& Rachman, N. F. (2019). Implementing microcontroller-based straight motion practicum media for improving scientific processing skills. Journal of Physics: Conference Series, 1273(1), 012030. https://doi.org/10.1088/1742-6596/1273/1/012030

Lederman, J., Lederman, N., Bartels, S., Jimenez, J., Akubo, M., Aly, S., Bao, C., Blanquet, E., Blonder, R., Bologna Soares de Andrade, M., Buntting, C., Cakir, M., EL-Deghaidy, H., ElZorkani, A., Gaigher, E., Guo, S., Hakanen, A., Hamed Al-Lal, S., Han-Tosunoglu, C., ... Zhou, Q. (2019). An international collaborative investigation of beginning seventh grade students' understandings of scientific inquiry: Establishing a baseline. Journal of Research in Science Teaching, 56(4), 486515. https://doi.org/10.1002/tea.21512

Malik, A., Setiawan, A., Suhandi, A., Permanasari, A., Samsudin, A., Safitri, D., Lisdiani, S. A. S., Sapriadil, S., \& Hermita, N. (2018). Using hot lab to increase pre-service physics teacher's critical thinking skills related to the topic of RLC circuit. Journal of Physics: Conference Series, 1013(1), 012023. https://doi.org/10.1088/1742-6596/1013/1/012023

Masrukan, M., \& Elmagustilla, S. R. (2020). Performance assessment of geometry mathematical representation ability viewed from student interest. Journal of Physics: Conference Series, 1567(2), 022104. https://doi.org/10.1088/1742-6596/1567/2/022104

Molvinger, K., Ayral, R.-M., \& Filhol, J.-S. (2020). Integrating lecture and laboratory work for a materials chemistry course to engage and motivate students through highly visual and intriguing syntheses. Journal of Chemical Education, 97(3), 866-872. 
https://doi.org/10.1021/acs.jchemed.9b00615

Mubarok, H., Lutfiyah, A., Kholiq, A., Suprapto, N., \& Putri, N. P. (2018). The performance assessment of undergraduate students in physics laboratory by using guided inquiry. Journal of Physics: Conference Series, 997(012039), 012039. https://doi.org/10.1088/1742-6596/997/1/012039

Mutlu, A., \& Şeşen, B. A. (2016). Impact of virtual chemistry laboratory instruction on pre-service science teachers' scientific process skills. SHS Web of Conferences, 26, 01088. https://doi.org/10.1051/shsconf/20162601088

Ohn, M., \& Ohn, K.-M. (2020). An evaluation study on gamified online learning experiences and its acceptance among medical students. Tzu Chi Medical Journal, 32(2), 211. https://doi.org/10.4103/tcmj.tcmj_5_19

Oktiawan, W., Hadiwodo, M., \& Purwono, P. (2019). Enhancement student understanding through the development of lab module based on constructivistic. International Journal of Engineering Education, 1(1), 41-45. https://doi.org/10.14710/ijee.1.1.41-45

Ramakrishnan, R., \& Kaur, A. (2020). An empirical comparison of predictive models for web page performance. Information and Software Technology, 123, 106307. https://doi.org/10.1016/j.infsof.2020.106307

Rodriguez, J.-M. G., \& Towns, M. H. (2018). Modifying laboratory experiments to promote engagement in critical thinking by reframing prelab and postlab questions. Journal of Chemical Education, 95(12), 2141-2147. https://doi.org/10.1021/acs.jchemed.8b00683

Siswanto, J., Susantini, E., \& Jatmiko, B. (2018). Practicality and effectiveness of the IBMR teaching model to improve physics problem solving skills. Journal of Baltic Science Education, 17(3), 381.

Susilaningsih, E., Khotimah, K., \& Nurhayati, S. (2018). Development of performance assessment instrument based contextual learning for measuring students laboratory skills. IOP Conference Series: Materials Science and Engineering, 349(1), 012018. https://doi.org/10.1088/1757899X/349/1/012018

Syaikhuddin, M. M., Anam, C., Rinaldi, A. R., \& Conoras, M. E. B. (2018). Conventional software testing using white box method. Kinetik: Game Technology, Information System, Computer Network, Computing, Electronics, and Control, 65-72. https://doi.org/10.22219/kinetik.v3i1.231

Topalsan, A. K. (2020). Development of scientific inquiry skills of science teaching through argumentfocused virtual laboratory applications. Journal of Baltic Science Education, 19(4), 628-646.

Wang, G., Bernanda, D. Y., Andry, J. F., Nurul Fajar, A., \& Sfenrianto. (2019). Application development and testing based on ISO 9126 framework. Journal of Physics: Conference Series, 1235(1), 012011. https://doi.org/10.1088/1742-6596/1235/1/012011 